\title{
NOTE ON THE SELECTIVITY OF MESHES USED BY THE SANTOS FISHING FLEET
}

(Received 12/5/61)

\author{
I. D. Richardson* \\ $\&$ \\ E. P. dos Santos**
}

CONTENTS

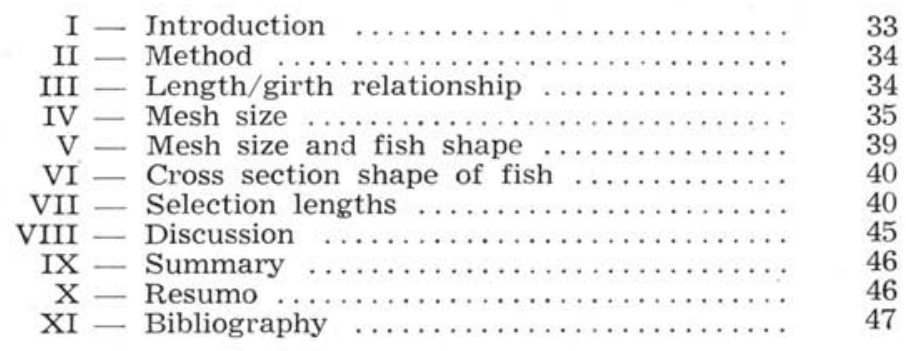

\section{I - INTRODUCTION}

In a paper (Richardson \& Moraes, 1960) describing the landings of marine fish made at Santos, in the State of São Paulo, Brazil, it was shown that an appreciable weight of fish was landed as "Mistura". "Mistura" is a market category composed of a number of different species, including those sold by name as prime fish, but which, because of their small size, are not acceptable at the price paid for the named species.

FAO Fisheries Expert on Technical Assistance assignement to Brazil.

** Instituto Oceanográfico da Universidade de São Paulo. Member of the "Grupo de Pesquisas sôbre a Pesca Maritima" (G.P.P.M.).

Publ. no 158 do Inst. Ocean. da USP.

Contr. n० 11 do G.P.P.M. 
Moreira (in preparation) gives a detailed analysis of the weight and numbers of each species included in "Mistura". He also points out that in addition to these small fish which are sold as "Mistura", a quantity of small fish is thrown overboard at sea, after each haul. For the three main commercial species ("Pescada-foguete", "Corvina" and "Goete"), the numbers of fish discarded at sea, those sold as "Mistura" and those sold by name, are in the proportion of $21: 1: 27$. He presents detailed evidence for this using observations made on the "Parelhinhas" (small Parejas), trawlers and the small shrimp trawlers.

Vazzoler (1962) showed that high percentage of immature fish are caught.

In this paper measurements of the actual mesh used in the cod-end of various types of gear used by the Santos fishing fleet are given. In addition, the theoretical selection length of these meshes for a number of commercially important species are calculated. Naturally, such a theoretical approach which uses a number of assumptions needs to be proved empirically for each species, and gear.

\section{II - METHOD}

The method adopted is similar to that shown in the paper by Lucas et al. (1954), Margetts (1957), and Beverton \& Holt (1957), and is based on the relation between fish size and mesh size. It has been assumed that girth is the deciding factor in selection.

\section{III - LENGTH/GIRTH RELATIONSHIP}

The three principal dragnet species, "Corvina" (Micropogon furnieri), "Goete" (Cynoscion petranus) and "Pescada-foguete" (Macrodon ancylodon) are examined, together with four secondary species: "Tortinha" (Isopisthus parvipinnis), "Cangauá" (Bairdiella ronchus), "Maria Luísa" (Paralonchurus brasiliensis) and "Oveva" (Larimus breviceps).

Measurements of the total length of fish landed in the fish market in Santos were made during the 12 months of 1960.

The measurements were made to the nearest millimetre using the total length from the snout to the tip of the caudal fin, slightly extended. The measurements were then grouped to the centimetre or $1 / 2$ centimetre below and 0.5 or $0.25 \mathrm{~cm}$ added to correct for 
this grouping. The measurements of girth were made by drawing a piece of twine round the maximum girth of the ungutted fish so as not to constrict the fish. The twine was then cut and measured to the nearest millimetre. Errors due to any increase in girth from blown airbladders are therefore included. No selection of the fish was made to distinguish between maturity stages.

The data obtained are shown in Tables $\mathrm{Ia}$ and $\mathrm{Ib}$ as mean girth per centimetre group. The number of individuals within each centimetre group is shown. These data are plotted in Figures $1 \mathrm{a}$ and $1 \mathrm{~b}$ using all points for which there are more than ten observations for Figure 1a and all points in $1 \mathrm{~b}$.

Regressions drawn by eye to pass through zero give the proportionality factors below:

Corvina Pescada-foguete Goete Tortinha Cangauá Maria Luísa Oveva

$\begin{array}{lllllll}1.71 & 2.20 & 1.90 & 1.96 & 1.62 & 2.03 & 1.46\end{array}$

Regressions fitted by least squares to the data give the following equations :

\begin{tabular}{lcc}
\multicolumn{1}{c}{$\begin{array}{c}\text { Gorvina } \\
\mathrm{G}=0.62 \mathrm{~L}-1.34\end{array}$} & $\mathrm{G}=0.59 \mathrm{~L}-1.42$ & $\mathrm{G}=0.53 \mathrm{~L}-2.04$ \\
$\mathrm{~L}=1.58 \mathrm{G}+2.40$ & $\mathrm{~L}=1.69 \mathrm{G}+2.30$ & $\mathrm{~L}=2.11 \mathrm{G}+1.30$ \\
& Tortinha & \\
& $\mathrm{G}=0.49 \mathrm{~L}+0.20$ & \\
& $\mathrm{~L}=1.98 \mathrm{G}-0.10$ & \\
& & \\
& Maria Luisa & Oveva \\
$\mathrm{G}=0.70 \mathrm{~L}-0.90$ & $\mathrm{G}=0.58 \mathrm{~L}-1.30$ & $\mathrm{G}=0.75 \mathrm{~L}-0.68$ \\
$\mathrm{~L}=1.41 \mathrm{G}+1.41$ & $\mathrm{~L}=1.69 \mathrm{G}+2.49$ & $\mathrm{~L}=1.29 \mathrm{G}+1.21$
\end{tabular}

IV - MESH SIZE

The mesh size was measured with the usual wedge shaped gauge. An error arises from the different amount of force used between measurements but efforts were made to standardize this at $2 \mathrm{~kg}$. At least 30 different cod-end mesh were measured on each net examined. All nets had been in use for some time and all measurements were made on nets in the wet or damp state. 
TABLE Ia - Numbers of fish at each centimetre length group together with the mean girth

\begin{tabular}{|c|c|c|c|c|c|c|c|c|}
\hline \multicolumn{3}{|c|}{ CORVINA } & \multicolumn{3}{|c|}{ PESCADA-FOGUETE } & \multicolumn{3}{|c|}{ GOETE } \\
\hline No. & $\begin{array}{l}\text { Length } \\
(\mathrm{cm})\end{array}$ & $\begin{array}{l}\text { Mean } \\
\text { girth } \\
(\mathrm{cm})\end{array}$ & No. & $\begin{array}{l}\text { Length } \\
(\mathrm{cm})\end{array}$ & $\begin{array}{l}\text { Mean } \\
\text { girth } \\
(\mathrm{cm})\end{array}$ & No. & $\begin{array}{l}\text { Length } \\
(\mathrm{cm})\end{array}$ & $\begin{array}{l}\text { Mean } \\
\text { girth } \\
(\mathrm{cm})\end{array}$ \\
\hline 2 & 4.5 & 2.0 & - & - & - & - & - & - \\
\hline 5 & 5.5 & 2.8 & 2 & 5.5 & 3.0 & 5 & 5.5 & 2.8 \\
\hline 14 & 6.5 & 3.1 & 3 & 6.5 & 2.7 & 5 & 6.5 & 3.2 \\
\hline 28 & 7.5 & 3.7 & 8 & 7.5 & 3.2 & 5 & 7.5 & 3.6 \\
\hline 36 & 8.5 & 4.1 & 12 & 8.5 & 3.6 & 3 & 8.5 & 4.7 \\
\hline 20 & 9.5 & 4.9 & 11 & 9.5 & 4.2 & 4 & 9.5 & 5.0 \\
\hline 2 & 10.5 & 5.0 & 22 & 10.5 & 4.3 & 7 & 10.5 & 6.1 \\
\hline 2 & 11.5 & 6.0 & 22 & 11.5 & 4.8 & 8 & 11.5 & 5.8 \\
\hline - & - & - & 21 & 12.5 & 5.3 & 11 & 12.5 & 6.4 \\
\hline - & - & - & 12 & 13.5 & 5.7 & 7 & 13.5 & 6.7 \\
\hline 10 & 14.5 & 7.9 & 12 & 14.5 & 6.1 & 5 & 14.5 & 6.8 \\
\hline 4 & 15.5 & 8.2 & 4 & 15.5 & 6.5 & 15 & 15.5 & 7.7 \\
\hline 6 & 16.5 & 9.2 & 5 & 16.5 & 7.4 & 21 & 16.5 & 8.1 \\
\hline 6 & 17.5 & 9.2 & 5 & 17.5 & 7.0 & 47 & 17.5 & 8.9 \\
\hline 10 & 18.5 & 9.8 & 15 & 18.5 & 7.7 & 66 & 18.5 & 9.3 \\
\hline 29 & 19.5 & 11.0 & 29 & 19.5 & 8.0 & 77 & 19.5 & 10.0 \\
\hline 39 & 20.5 & 11.3 & 37 & 20.5 & 8.6 & 113 & 20.5 & 10.6 \\
\hline 65 & 21.5 & 12.1 & 60 & 21.5 & 9.0 & 97 & 21.5 & 11.3 \\
\hline 79 & 22.5 & 12.8 & 70 & 22.5 & 9.4 & 99 & 22.5 & 11.8 \\
\hline 103 & 23.5 & 13.3 & 91 & 23.5 & 9.9 & 103 & 23.5 & 12.5 \\
\hline 111 & 24.5 & 14.2 & 97 & 24.5 & 10.4 & 83 & 24.5 & 13.2 \\
\hline 125 & 25.5 & 14.6 & 103 & 25.5 & 11.2 & 78 & 25.5 & 13.6 \\
\hline 152 & 26.5 & 15.2 & 124 & 26.5 & 11.7 & 77 & 26.5 & 14.1 \\
\hline 196 & 27.5 & 15.9 & 165 & 27.5 & 12.2 & 58 & 27.5 & 14.8 \\
\hline 196 & 28.5 & 16.4 & 173 & 28.5 & 12.8 & 31 & 28.5 & 15.3 \\
\hline 218 & 29.5 & 17.1 & 193 & 29.5 & 13.3 & 25 & 29.5 & 16.2 \\
\hline 216 & 30.5 & 17.6 & 192 & 30.5 & 13.9 & 7 & 30.5 & 16.8 \\
\hline 199 & 31.5 & 18.3 & 172 & 31.5 & 14.5 & 4 & 31.5 & 17.0 \\
\hline 203 & 32.5 & 19.0 & 155 & 32.5 & 15.0 & 2 & 32.5 & 18.0 \\
\hline 206 & 33.5 & 19.8 & 145 & 33.5 & 15.7 & - & - & - \\
\hline 171 & 34.5 & 20.6 & 129 & 34.5 & 16.2 & - & - & - \\
\hline 160 & 35.5 & 21.4 & 133 & 35.5 & 16.6 & - & - & - \\
\hline 141 & 36.5 & 22.1 & 106 & 36.5 & 17.1 & - & - & - \\
\hline 145 & 37.5 & 22.6 & 97 & 37.5 & 17.6 & - & - & - \\
\hline 110 & 38.5 & 22.5 & 78 & 38.5 & 18.2 & - & - & - \\
\hline 104 & 39.5 & 23.2 & 52 & 39.5 & 18.6 & - & - & - \\
\hline 94 & 40.5 & 23.8 & 36 & 40.5 & 19.6 & - & - & - \\
\hline 86 & 41.5 & 24.5 & 19 & 41.5 & 20.4 & - & - & - \\
\hline 67 & 42.5 & 25.2 & 18 & 42.5 & 20.2 & - & - & - \\
\hline 71 & 43.5 & 25.6 & - & - & - & - & - & - \\
\hline 58 & 44.5 & 26.6 & - & - & - & - & - & - \\
\hline 45 & 45.5 & 26.6 & - & - & - & - & - & - \\
\hline 33 & 46.5 & 27.8 & - & - & - & - & - & - \\
\hline 32 & 47.5 & 28.5 & - & - & - & - & - & - \\
\hline 36 & 48.5 & 29.0 & - & - & - & - & - & - \\
\hline 19 & 49.5 & 30.5 & - & - & - & - & - & - \\
\hline 26 & 50.5 & 30.2 & - & - & - & - & - & - \\
\hline 3,680 & & & 2,628 & & & 1,063 & & \\
\hline
\end{tabular}


TABLE Ib - Numbers of fish at each centimetre length group together with the mean girth

\begin{tabular}{|c|c|c|c|c|c|c|c|c|c|c|c|}
\hline \multicolumn{3}{|c|}{ TORTINHA } & \multicolumn{3}{|c|}{ CANGAUA } & \multicolumn{3}{|c|}{ MARIA LUISA } & \multicolumn{3}{|c|}{ OVEVA } \\
\hline 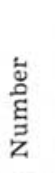 & 壱哭 & 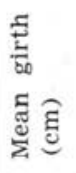 & 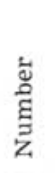 & 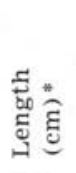 & 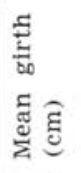 & $\frac{\grave{\Xi}}{\frac{\Xi}{\Xi}}$ & 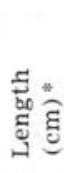 & 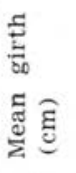 & 鴶 & 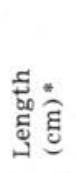 & 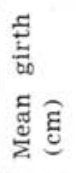 \\
\hline 2 & 5.5 & 3.2 & 2 & 7.5 & 4.5 & 1 & 10.5 & 5.0 & 4 & 6.5 & 4.5 \\
\hline 4 & 6.0 & 3.0 & 4 & 8.0 & 4.9 & 1 & 11.0 & 5.0 & 2 & 7.0 & 4.2 \\
\hline 5 & 6.5 & 3.4 & 5 & 8.5 & 5.0 & 3 & 11.5 & 5.5 & 3 & 7.5 & 5.2 \\
\hline 3 & 7.0 & 3.8 & 6 & 9.0 & 4.9 & 8 & 12.0 & 5.7 & 5 & 8.0 & 5.1 \\
\hline 7 & 7.5 & 3.7 & 6 & 9.5 & 5.5 & 4 & 12.5 & 6.2 & 5 & 8.5 & 6.0 \\
\hline 4 & 8.0 & 4.2 & 4 & 10.0 & 6.0 & 5 & 13.0 & 6.1 & 4 & 9.0 & 5.5 \\
\hline 6 & 8.5 & 4.5 & 8 & 10.5 & 6.6 & 5 & 13.5 & 6.5 & 3 & 9.5 & 6.3 \\
\hline 3 & 9.0 & 4.5 & 6 & 11.0 & 7.0 & 6 & 14.0 & 6.7 & 3 & 10.0 & 7.0 \\
\hline 8 & 9.5 & 4.6 & 6 & 11.5 & 7.4 & 6 & 14.5 & 7.2 & 4 & 10.5 & 7.0 \\
\hline 9 & 10.0 & 4.9 & 6 & 12.0 & 7.6 & 4 & 15.0 & 7.5 & 3 & 11.0 & 7.7 \\
\hline 8 & 10.5 & 5.4 & 4 & 12.5 & 7.7 & 6 & 15.5 & 7.7 & 4 & 11.5 & 8.5 \\
\hline 10 & 11.0 & 5.6 & 5 & 13.0 & 8.2 & 6 & 16.0 & 8.2 & 3 & 12.0 & 8.7 \\
\hline 13 & 11.5 & 6.2 & 4 & 13.5 & 8.5 & 5 & 16.5 & 8.4 & 2 & 12.5 & 8.2 \\
\hline 17 & 12.0 & 6.4 & 4 & 14.0 & 9.0 & 6 & 17.0 & 8.3 & 3 & 13.0 & 9.5 \\
\hline 11 & 12.5 & 6.4 & 1 & 14.5 & 9.0 & 4 & 17.5 & 8.6 & 5 & 13.5 & 9.7 \\
\hline 3 & 13.0 & 6.8 & - & - & - & 4 & 18.0 & 9.2 & 3 & 14.0 & 9.3 \\
\hline 3 & 13.5 & 6.3 & - & - & - & 4 & 18.5 & 9.9 & 2 & 14.5 & 10.0 \\
\hline 4 & 14.0 & 7.0 & - & - & - & 3 & 19.0 & 10.0 & - & - & - \\
\hline 4 & 14.5 & 7.6 & - & - & - & 2 & 19.5 & 10.0 & - & - & - \\
\hline 124 & & & 71 & & & 83 & & & 58 & & \\
\hline
\end{tabular}

* Without correction of $0.25 \mathrm{~cm}$.

In Table II the type of boat, type of net, the number of measurements and the mean mesh size is shown for each boat.

In Table III the mean mesh size using all the individual measurements for each type of net and size category of boat are shown, together with the standard deviation. As all Brazilian nets were made of cotton (usually size 3 ) and Japanese nets had nylon cod-ends, the two are separated. Apart from the difference in 
TABLE II

\begin{tabular}{|c|c|c|c|c|c|c|}
\hline * & & Size & Type of net & $\begin{array}{l}\text { Mean mesh } \\
(\mathrm{cm})\end{array}$ & $\begin{array}{l}\text { Standard } \\
\text { deviation }\end{array}$ & $\begin{array}{l}\text { Number of } \\
\text { observations }\end{array}$ \\
\hline Braz. & 1 & Medium & Otter trawl & 7.8 & 0.3 & 120 \\
\hline$"$ & 2 & $"$ & $" \quad "$ & 7.2 & 0.3 & 60 \\
\hline$"$ & 3 & $"$ & Pareja trawl & 7.2 & 0.4 & 27 \\
\hline$n$ & 4 & Small & $" \quad "$ & 6.6 & 0.4 & 30 \\
\hline$"$ & 5 & Medium & $"$ & 6.6 & 0.3 & 90 \\
\hline$"$ & 6 & $"$ & $"$ & 6.8 & 0.3 & 60 \\
\hline$"$ & 7 & $"$ & $"$ & 7.2 & 0.4 & 84 \\
\hline$"$ & 8 & $"$ & $"$ & 7.6 & 0.6 & 60 \\
\hline$"$ & 9 & $"$ & $"$ & 7.0 & 0.4 & 90 \\
\hline$"$ & 10 & $"$ & $"$ & 6.6 & 0.3 & 60 \\
\hline$"$ & 11 & $"$ & $"$ & 7.6 & 0.4 & 30 \\
\hline$"$ & 12 & Small & $"$ & 6.4 & 0.1 & 44 \\
\hline$"$ & 13 & $"$ & $"$ & 7.4 & 0.4 & 50 \\
\hline$"$ & 14 & $"$ & $"$ & 7.8 & 0.6 & 30 \\
\hline$"$ & 15 & $"$ & $"$ & 7.4 & 0.5 & 90 \\
\hline “ & 16 & $"$ & $"$ & 7.0 & 0.3 & 60 \\
\hline$"$ & 17 & Medium & Otter trawl & 7.4 & 0.4 & 90 \\
\hline$"$ & 18 & $"$ & Pareja trawl & 7.8 & 0.5 & 90 \\
\hline Jap. & 1 & Large & $" \quad " \quad$ & 13.6 & 0.2 & 30 \\
\hline Braz. & 19 & Small & Otter trawl & 4.8 & 0.2 & 90 \\
\hline$"$ & 20 & $"$ & $" \quad "$ & 4.8 & 0.2 & 90 \\
\hline
\end{tabular}

* The names of the boats, in the first column, have been purposely omitted.

TABLE III

\begin{tabular}{|c|c|c|}
\hline Category of boat & $\begin{array}{l}\text { Mean mesh size } \\
(\mathrm{cm})\end{array}$ & Standard deviation \\
\hline Otter trawl: & & \\
\hline Medium otter trawl $\ldots \ldots \ldots \ldots \ldots \ldots \ldots$ & 7.4 & 0.3 \\
\hline $\begin{array}{l}\text { Small otter trawl } \ldots \ldots \ldots \ldots \ldots \ldots \ldots \ldots \ldots \ldots \\
\text { Pareja trawl: }\end{array}$ & 4.8 & 0.2 \\
\hline Medium pareja trawl $\ldots \ldots \ldots \ldots \ldots \ldots$ & 7.2 & 0.4 \\
\hline $\begin{array}{l}\text { Small pareja trawl } \ldots \ldots \ldots \ldots \ldots \ldots \ldots \ldots \ldots \\
\text { (Japanese) }\end{array}$ & 7.2 & 0.4 \\
\hline Large pareja trawl $\ldots \ldots \ldots \ldots \ldots \ldots \ldots$ & 13.6 & 0.2 \\
\hline
\end{tabular}


material used, there is a big difference in mesh size between the Japanese and Brazilian boats. The mean mesh size of the small and medium parejas and the medium trawlers of the Brazilian fleet are very similar. The three size categories of the boats are: small - less than $10 \mathrm{~m}$ in length; medium, between 10 and $20 \mathrm{~m}$, and large, over $20 \mathrm{~m}$.

To arrive to the lumen size the figures in Table III must be multiplied by 2 and $0.24 \mathrm{~cm}$ added to correct for the thickness of the gauge.

\section{$\mathrm{V}$ - MESH SIZE AND FISH SHAPE}

The mesh may be considered to be perfectly flexible or perfectly rigid. If it is rigid the shape of the mesh is important. The limits used in this paper are at the one extreme a perfectly flexible mesh and at the other extreme a rigid mesh with a ratio of $2: 3$ between the horizontal and vertical axes. This mesh shape is similar to that observed in the film "Trawls in Action", made by the Fisheries Laboratory, Lowestoft, and has been shown by Margetts (op. cit.) and Beverton \& Holt (op. cit.) to be acceptable when used in theoretical calculations in comparison with observed results in manila or sisal double braided cod-ends.

Lucas et al. (op. cit.) and Graham (1954) showed that a cotton mesh as used in the Danish seine gave higher selection lengths, suggesting that material or the mesh shape was more flexible. Without actual observations on the shape of the mesh in the cod-end of commercial boats fishing from Santos it is not possible to use a more accurate estimate of the shape than those extremes which have been taken. Clearly, because of the different designs of the nets used and the different material used in the construction of the net, there must be a wide range both in mesh shape and rigidity. The completely flexible mesh will theoretically give an equal chance of escape and retention to a fish of which has the same circumference as the perimeter of the mesh (neglecting any effect of constriction).

The fish of circular cross section in a rigid mesh of $2: 3$ axis ratio will have a girth of $72 \%$ of the mesh perimeter, as calculated from the formula:

$$
\frac{G}{M}=\frac{\pi a b}{2\left(a^{2}+b^{2}\right)}
$$

where $a$ and $b$ are the $1 / 2$ axes of the mesh, $G$ the girth of fish, and $M$ the internal perimeter of the mesh. 


\section{VI - CROSS SECTION SHAPE OF FISH}

In practice the fish form is not circular, although for practical purposes it may perhaps be regarded as circular in the region of the body where maximum girth occurs. Cross sections of "Corvina", "Pescada-foguete" and "Goete" are shown in Figure 2. These cross sections were made by drawing round freshly cut ungutted fish. It was found that the cross section shape, as described by the ratio vertical/horizontal axes of the fish tended to change somewhat with increase in length (Table IV). This tendency is not significant.

The internal perimeter of a mesh which would allow fish having the cross sectional form shown in Figure 2 to pass without distortion of the mesh or fish was calculated for each fish in Table IV. The mesh was assumed to be rigid with horizontal and vertical axes in the ratio of $2: 3$. The required size of mesh of each fish is shown in Table V. Using these data it is possible to express fish girth as a percentage of mesh perimeter. These results were plotted and fitted with a linear regression passing through the origin. This gives the girth of a fish as $78 \%$ of the mesh for "Corvina", $82 \%$ for "Goete", and $76 \%$ for "Pescada-foguete", and assumes no distortion of the fish from its natural cross sectional shape, or distortion of the rigid mesh. As few data were available and because the cross sectional form is not constant for all lengths, these percentage can only be regarded as approximate. However, they serve to show that if the fish was incapable of distortion from the normal form and did not approximate to the circular form, there would be little difference in the mesh size required.

Because of the small difference between circular and normal form the fish is considered to be circular in cross section in later calculations. It has also been assumed that the fish is incapable of being constricted as it passes through the mesh. This is clearly erroneous, but as the degree of constriction, which to some extent depends on the swimming power, is unknown, it is necessary to adopt this assumption.

\section{VII - SELECTION LENGTHS}

The equations derived earlier in this paper, which express the relation between length and girth, are valid for the case in which the fish is regarded as circular in cross section and the mesh is perfectly flexible. It is only necessary to substitute $M$ 


\begin{tabular}{|c|c|c|c|c|c|c|c|c|c|c|}
\hline \multirow{4}{*}{ 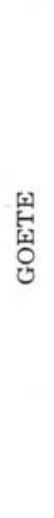 } & $\widehat{\Psi} \mid \geqslant$ हु & $\overrightarrow{\mathrm{d}}$ & $\stackrel{\circ}{\text { ì }}$ & $\overleftrightarrow{\text { SH}}$ & 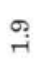 & $\stackrel{\vec{N}}{\text { i }}$ & 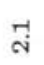 & $\underset{\sim}{*}$ & $\stackrel{\sim}{\mathrm{H}}$ & 1 \\
\hline & 豆 & ๙ิ & $\stackrel{\circ}{\mathrm{i}}$ & $\stackrel{\infty}{\sim}$ & $\stackrel{\infty}{i}$ & ๙n & $\begin{array}{l}\stackrel{0}{\sim} \\
\text { in }\end{array}$ & $\stackrel{\varphi}{\circ}$ & $\stackrel{\ominus}{\text { மे }}$ & 1 \\
\hline & 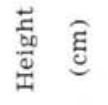 & $\stackrel{r}{\sim}$ & नु & भ̊ & is & $\begin{array}{l}10 \\
10\end{array}$ & $\begin{array}{l}10 \\
\text { is }\end{array}$ & ֻै & ำ & 1 \\
\hline & 㔛 & 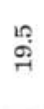 & $\stackrel{\circ}{\infty} \underset{\sim}{\stackrel{0}{l}}$ & ¿্் & 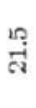 & $\stackrel{\circ}{\stackrel{\otimes}{~}}$ & เุ & $\begin{array}{l}\text { ㅁ. } \\
\text { a }\end{array}$ & 呙 & 1 \\
\hline \multirow{4}{*}{ 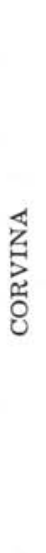 } & 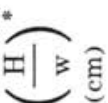 & ๙ึ & $\vec{d}$ & $\stackrel{\leftrightarrow}{\sim}$ & శึ & ชิ & ণิ & 1 & 1 & 1 \\
\hline & 氖 & $\stackrel{\oplus}{\infty}$ & $\stackrel{\varphi}{+}$ & $\begin{array}{l}\infty \\
\text { ஸे }\end{array}$ & : & بִ & นึ้ & 1 & 1 & 1 \\
\hline & 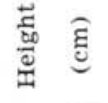 & $\underset{\infty}{\infty}$ & $\stackrel{\bullet}{\circ}$ & $\stackrel{\infty}{\infty}$ & $\stackrel{12}{=}$ & to & $\stackrel{13}{2}$ & 1 & 1 & 1 \\
\hline & 䓌 & กิं & 约 & $\stackrel{\circ}{\circ}$ & $\stackrel{\circ}{\mathscr{\leftrightarrow}}$ & $\begin{array}{l}10 \\
\text { Ig }\end{array}$ & $\begin{array}{l}10 \\
\stackrel{10}{0}\end{array}$ & 1 & I & I \\
\hline \multirow{4}{*}{ 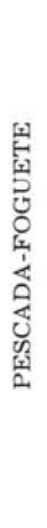 } & & $\underset{+}{\sigma}$ & $\stackrel{\circ}{-}$ & $\stackrel{\circ}{\mathrm{i}}$ & $\vec{\sim}$ & สี & ته & $\stackrel{\leftrightarrow}{\mathrm{s}}$ & ภี & તู \\
\hline & 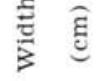 & $\stackrel{\circ}{\text { ì }}$ & $\stackrel{t}{\widehat{t}}$ & $\stackrel{\circ}{\circ}$ & $\stackrel{\text { ஸे }}{\text { iे }}$ & $\stackrel{\theta}{\hat{d}}$ & Fi & $\stackrel{r}{n}$ & $\begin{array}{l}\text { के } \\
\text { ळ. }\end{array}$ & $\stackrel{\varphi}{\oplus}$ \\
\hline & 点 & $\stackrel{\infty}{\infty}$ & $\stackrel{\text { Ji }}{*}$ & $\begin{array}{l}0 \\
10\end{array}$ & ָุ & $\begin{array}{l}10 \\
0 \\
0\end{array}$ & $\stackrel{\overbrace{}}{\sim}$ & $\stackrel{\varphi}{\circ}$ & $\stackrel{t}{\infty}$ & $\stackrel{\text { Sִ }}{\Gamma}$ \\
\hline & 营 & त़ & ָึ & ฝึ & 요 & 官 & ले & ஜिं & ले & 1ึి \\
\hline
\end{tabular}




\begin{tabular}{|c|c|c|c|c|c|c|c|c|c|}
\hline \multirow{3}{*}{ 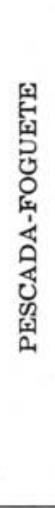 } & 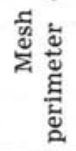 & 어 & $\begin{array}{l}\stackrel{\varphi}{ } \\
\stackrel{+}{+}\end{array}$ & ๗ุ & ํㅗㅁ & 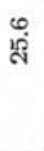 & $\begin{array}{l}\infty \\
\text { స్ }\end{array}$ & 1 & 1 \\
\hline & 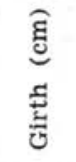 & $\begin{array}{l}\text { 占 } \\
\text { Iñ }\end{array}$ & $\begin{array}{l}\stackrel{0}{\oplus} \\
\stackrel{\leftrightarrow}{-1}\end{array}$ & & $\begin{array}{l}0 \\
\text { D) } \\
\text { di }\end{array}$ & $\begin{array}{l}\stackrel{\circ}{+} \\
\text { के }\end{array}$ & $\begin{array}{l}\stackrel{0}{\infty} \\
\stackrel{0}{\sim}\end{array}$ & 1 & 1 \\
\hline & 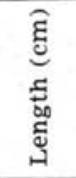 & @̊. & $\begin{array}{l}\text { ñ } \\
\text { อ̊ }\end{array}$ & ले & $\begin{array}{l}\text { in } \\
\text { ले }\end{array}$ & लें & $\begin{array}{l}\text { ஸ़ } \\
\text { ஸे }\end{array}$ & 1 & 1 \\
\hline \multirow{3}{*}{ 쇱 } & 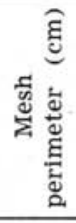 & ત્ર & $\stackrel{\circ}{\stackrel{+}{+}}$ & $\begin{array}{c}\stackrel{0}{\circ} \\
\stackrel{\leftrightarrow}{n}\end{array}$ & సָ & $\begin{array}{l}0 \\
\dot{\oplus}\end{array}$ & $\begin{array}{l}\stackrel{0}{0} \\
\stackrel{+}{0}\end{array}$ & ָุ & 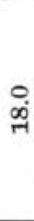 \\
\hline & 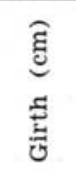 & $\stackrel{\circ}{\circ}$ & $\stackrel{\text { In }}{\stackrel{\text { In }}{\circ}}$ & 우 & 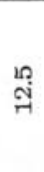 & $\stackrel{\circ}{\underset{+}{+}}$ & 감 & 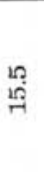 & 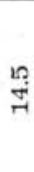 \\
\hline & 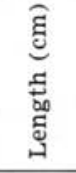 & $\begin{array}{l}\stackrel{0}{\infty} \\
\stackrel{+}{+}\end{array}$ & 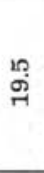 & @̊ & $\begin{array}{l}\text { ה! } \\
\text { ñ }\end{array}$ & ஷें & ปn & 品 & 옹 \\
\hline \multirow{3}{*}{ 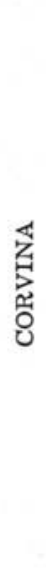 } & 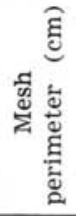 & $\begin{array}{l}\mathscr{N} \\
\text { गे }\end{array}$ & $\begin{array}{l}\infty \\
\text { do } \\
\text { di }\end{array}$ & స్ & $\begin{array}{l}\infty \\
\text { ⿵ై }\end{array}$ & ભ̊ & $\stackrel{\mathscr{m}}{\dot{m}}$ & 1 & 1 \\
\hline & 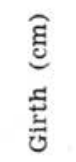 & 옴 & 올 & तึ & ํ. & $\begin{array}{l}\text { 10 } \\
\text { నุ }\end{array}$ & స్ & 1 & 1 \\
\hline & 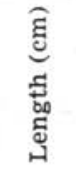 & 이 & $\begin{array}{l}10 \\
\infty \\
\infty \\
\infty\end{array}$ & $\stackrel{\circ}{\circ}$ & $\begin{array}{l}\stackrel{\circ}{\mathscr{H}} \\
\dot{q}\end{array}$ & $\begin{array}{l}\text { 10 } \\
\text { gु }\end{array}$ & $\begin{array}{l}10 \\
\mathscr{f} \\
\mathscr{f}\end{array}$ & 1 & 1 \\
\hline
\end{tabular}


for $G$ where $M$ is the internal mesh perimeter. If the fish is assumed to be circular but the mesh rigid, the following relationship exists :

$\begin{array}{ll}\text { "Corvina" } & L=1.14 M+2.40 \\ \text { "Pescada-foguete" } & L=1.52 M+1.30 \\ \text { "Goete" } & L=1.22 M+2.30 \\ \text { "Tortinha" } & L=1.42 M-0.10 \\ \text { "Cangauá" } & L=1.02 M+1.41 \\ \text { "Maria Luísa" } & L=1.22 M+2.49 \\ \text { "Oveva" } & L=0.93 M+1.21\end{array}$

The two regressions for each species are shown in Figures $3 \mathrm{a}$ and $3 \mathrm{~b}$ and from them the selection lengths of a mesh of given size can be read off as the maximum and minimum $50 \%$ selection length which could be expected. Somewhere between these two extremes lies the true selection length depending on the flexibility of the mesh and the swimming power of the fish.

For simplicity, proportionality factors can be given, although such factors include an error not found in the fitted equations previously cited. They are as follows:

\begin{tabular}{|c|c|c|}
\hline & $\begin{array}{l}\text { ular cross section } \\
\text { flexible mesh }\end{array}$ & $\begin{array}{c}\text { Circular cross section } \\
\text { rigid mesh }\end{array}$ \\
\hline “Corvina” & $L=1.71 M$ & $L=1.26 M$ \\
\hline "Pescada-foguete" & $L=2.20 \mathrm{M}$ & $L=1.63 \mathrm{M}$ \\
\hline "Goete" & $L=1.90 M$ & $L=1.40 M$ \\
\hline "Tortinha" & $L=1.96 M$ & $L=1.45 M$ \\
\hline "Cangauá" & $L=1.62 M$ & $L=1.20 \mathrm{M}$ \\
\hline "Maria Luísa" & $L=2.03 M$ & $L=1.50 M$ \\
\hline “Oveva" & $L=1.46 \mathrm{M}$ & $L=1.08 \mathrm{M}$ \\
\hline
\end{tabular}

The mesh sizes in the cod-end of the commercial fleet fishing out of Santos, shown in Table IV, are drawn in Figure 3, and below the calculated maximum and minimum selection lengths are given. Because of the similarity in mesh size between the small and medium parejas and the medium trawlers, a mean of $7.3 \mathrm{~cm}$ has been taken. 


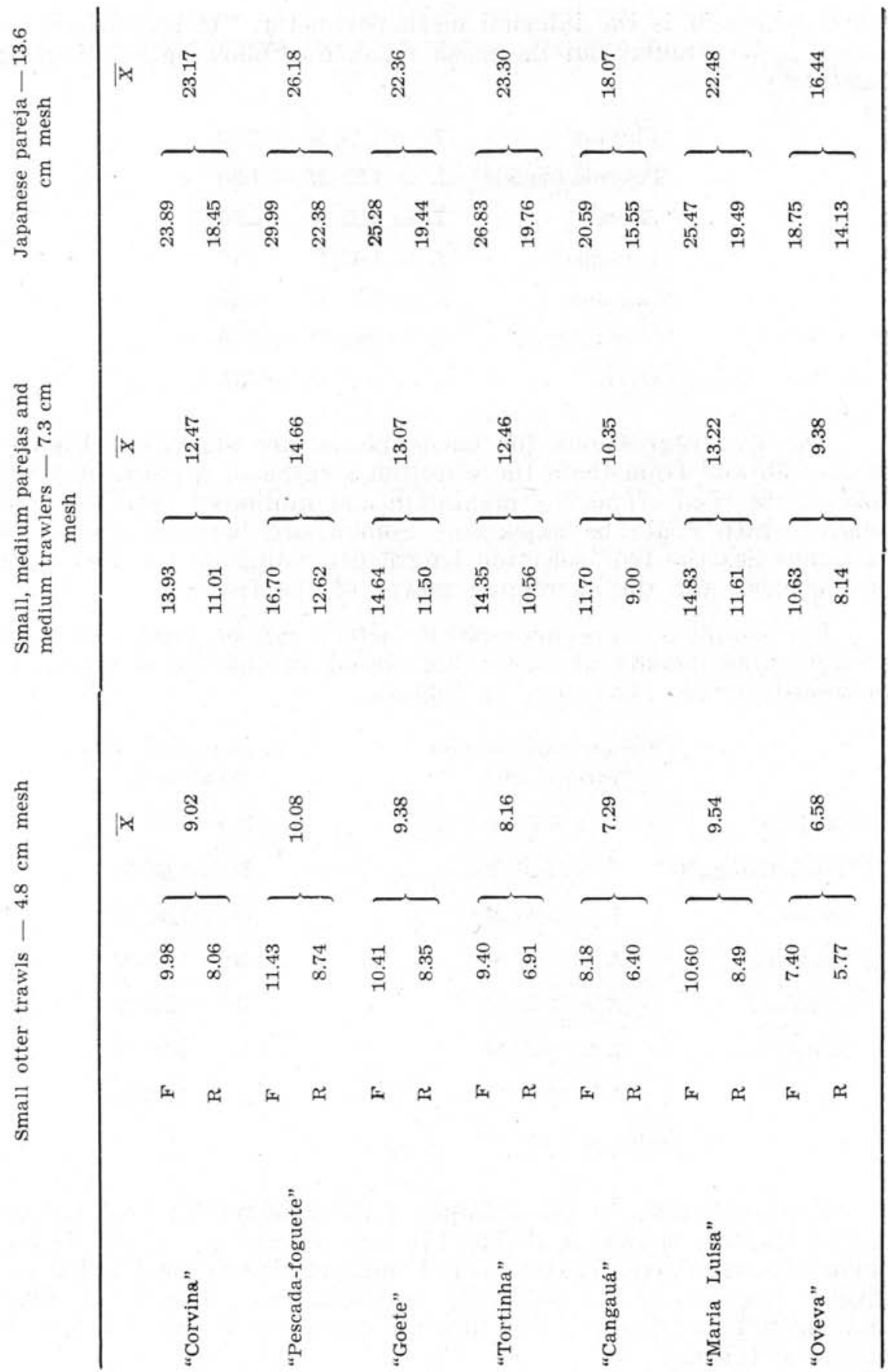


The nylon of the Japanese nets is probably more flexible than cotton and the actual selection lengths probably tend towards the higher limit. The less flexible cotton and also the smaller mesh size will tend to give a more rigid mesh, so the selection lengths will fall towards the lower limit.

Experiments with covered cod-ends of cotton mesh of internal perimeter $10.8 \mathrm{~cm}$ give, according to Moreira (op. cit.), a $50 \%$ selection point for "Corvina" at $16.45 \mathrm{~cm}$, "Oveva" at $12.40 \mathrm{~cm}$, "Cangauá" at $14.80 \mathrm{~cm}$, and "Maria Luísa" at $17.70 \mathrm{~cm}$.

From the equations derived earlier, "Corvina" of $16.45 \mathrm{~cm}$ has a girth of $8.83 \mathrm{~cm}$, which is $82 \%$ of the mesh perimeter, "Oveva" of $12.40 \mathrm{~cm}$ has a girth of $8.68 \mathrm{~cm}$ and occupies $80 \%$ of the mesh, "Cangauá" of $14.80 \mathrm{~cm}$ has a girth of $9.50 \mathrm{~cm}$ and occupies $88 \%$ of the mesh, "Maria Luísa" of $17.70 \mathrm{~cm}$ has a girth of $9.58 \mathrm{~cm}$ and occupies $83 \%$ of the mesh. The other three species included in the work of Moreira give percentage between 80 and 88.

\section{VIII - DISCUSSION}

In this paper only seven species of fish are considered. They are the most important dragnet species fished from Santos but other species of fish and shrimp are also caught with these nets.

In this paper we used the limits of $72 \%$ and $100 \%$. The results of Moreira show that either the mesh is not absolutely rigid, or does not have exactly the shape assumed by us of $2: 3$ thus the selection lengths would be better expressed had we used $80-88 \%$. This true selection value is approximately intermediate between the limits taken by us and shown in Figures $3 \mathrm{a}$ and $3 \mathrm{~b}$ for cotton nets used by Brazilian boats. However, if the largest possible length is considered (on the assumption that the mesh is flexible), for all seven species the selected lengths lie below $17.0 \mathrm{~cm}$. From the Tables of market length measurements (published annually by "Grupo de Pesquisas sôbre a Pesca Marítima") and from the works already cited on the three species, it can be seen that until the fish are $22-23 \mathrm{~cm}$ they are not landed and sold by the name of the species, as there is no demand for them at this size.

All Brazilian boats are therefore using meshes which are killing species at a size unacceptable on the market. The Japanese boats, because of the larger nets, may be catching some fish of a size which is not marketable, but the minimum selection length is closer to the minimum acceptable market length. This can be seen from the similarity in the selection lengths calculated in this 
paper and the mean size of the fish landed. The Japanese boats sell their fish already divided into boxes of small, medium and large fish. The mean length of the category called small is 22.11 cm for "Pescada-foguete", which is very little lower than the minimum theoretical selection length of $22.38 \mathrm{~cm}$ derived earlier.

Apart from the economic wastage, the effect of these mesh sizes on the stock should be remembered. From the works already cited it can be seen that all the lengths derived earlier fall within the first or second year of the fishes life, when the fish are immature and before they have reached the peak of the growth curve. This killing of young immature fish must prejudice the stock but to what extent and whether to an extent of sufficient importance to merit suggesting a change of mesh on biological grounds alone, is unknown, and needs further investigation.

\section{IX - SUMMARY}

In this paper the relationship between total length and girth (circumference) of seven species: "Corvina" (Micropogon furnieri), "Pescada-foguete" (Macrodon ancylodon), "Goete" (Cynoscion petranus), "Tortinha" (Isopisthus parvipinnis), "Cangauá" (Bairdiella ronchus), "Maria Luísa" ("Paralonchurus brasiliensis), and "Oveva" (Larimus breviceps), are expressed in the form of fitted regressions. Theoretical selection lengths assuming, at the one extreme, the mesh to be completely flexible, and at the other extreme to be rigid with axes of $2: 3$ are calculated. The fish is assumed to be able to adopt a circular cross section. If the fish is not circular but retains its normal form, the difference in the selection length is shown to be little different.

The Brazilian commercial boats fishing from Santos are shown to use a mesh which has a very low selection point well below the size of fish which are acceptable on the fish market. The Japanese boats use a much larger mesh, which select fish of marketable size.

\section{$\mathrm{X}-\mathrm{RESUMO}$}

Neste trabalho, adotou-se o método empregado por Lucas et al. (1954), Margetts (1957) e Beverton \& Holt (1957), para o estudo da seletividade, produzida pelas malhas das rêdes da frota pesqueira de Santos, sôbre as seguintes espécies: "Corvina" (Micropogon furnieri), "Pescada-foguete" (Macrodon ancylodon), "Goete" (Cynoscion petranus), "Tortinha" (Isopisthus parvipinnis), Cangauá" (Bairdiella ronchus), "Maria Luísa" (Paralonchurus brasiliensis) e "Oveva" (Larimus breviceps).

$\mathrm{O}$ estudo baseou-se nas seguintes hipóteses: primeiramente, que a malha fôsse completamente flexível, em segundo lugar, completamente rígida, com as proporções de 2:3 entre as diagonais e em terceiro lugar, que o peixe pudesse tomar secção transversal circular.

Através de retas de regressão, foram estabelecidas correlações entre a malha, nas duas situações e o comprimento do peixe, com $50 \%$ de probabilidade de escape. 
Concluiu-se que os barcos brasileiros da frota, devido à malhagem pequena, capturam peixes de comprimento inferior ao aceito pelo mercado, produzindo depredação, o que não acontece com os barcos japonêses.

\section{XI - BIBLIOGRAPHY}

Beverton, R. J. H. \& Holt, S. J.

1957. On the dynamics of exploited fish population. Fish. Invest., series II, vol. XIX, $533 \mathrm{p}$.

GrahaM, M.

1954. Trials of mesh selection in trawls and seines. Jour. du Cons., vol. 20, n. $^{\circ} 1$, p. 62-71.

LuCAS, C. E. et al.

1954. Mesh selection in the roundfish seine. Jour. du Cons., vol. 20, n. ${ }^{\circ}$ 1, p. 35-50.

Margetts, A. R.

1957. The length-girth relationships in whiting and cod and their application to mesh selection. Jour. du Cons., vol. 23, n. ${ }^{\circ} 1$.

MOREIRA, P. S.

Quantidade dos peixes rejeitados pela frota comercial de Santos e observações sôbre a seletividade de malhas de $54 \mathrm{~mm}$. (In preparation)

Richardson, I. D. \& Moraes, M. N. de

1960. A first appraisal of the landing and mechanism of the Santos fishery. Bol. Inst. Ocean., vol. XI, n. ${ }^{\circ}$, p. 5-86.

VAzZoler, A. E. A. M.

1962. Sôbre a primeira maturação sexual e destruição de peixes imaturos. Bol. Inst. Ocean., vol. XII, n. ${ }^{\circ} 2$. 


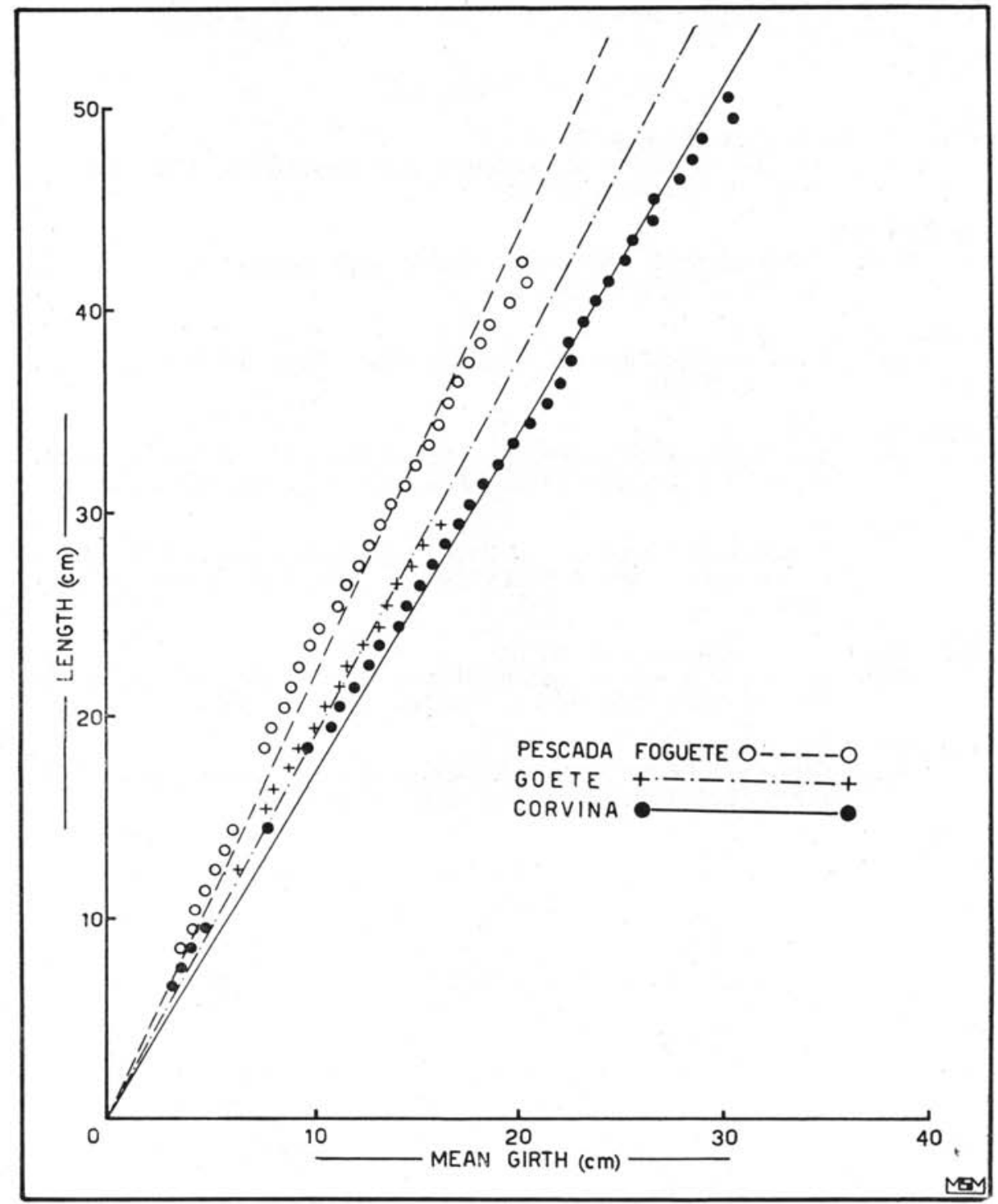

Fig. 1a - Data from Table Ia of mean girth per centimetre group were plotted where more than ten observations were available per centimetre length group. Regressions drawn by eye through zero are shown. 


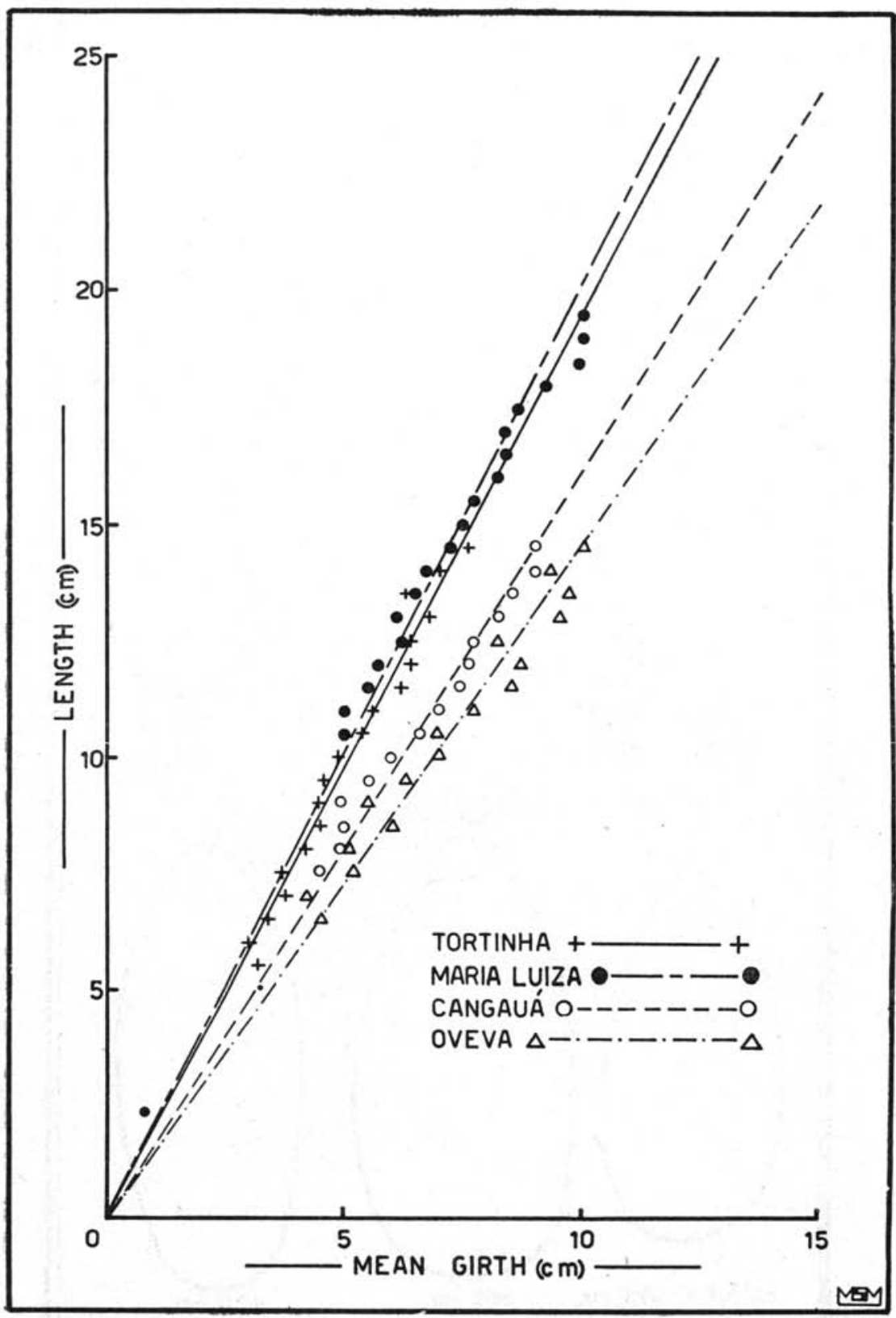

Fig. 1b - Data from Table Ib of mean girth per centimetre group are plotted. Regressions drawn by eye to pass through zero are shown. 


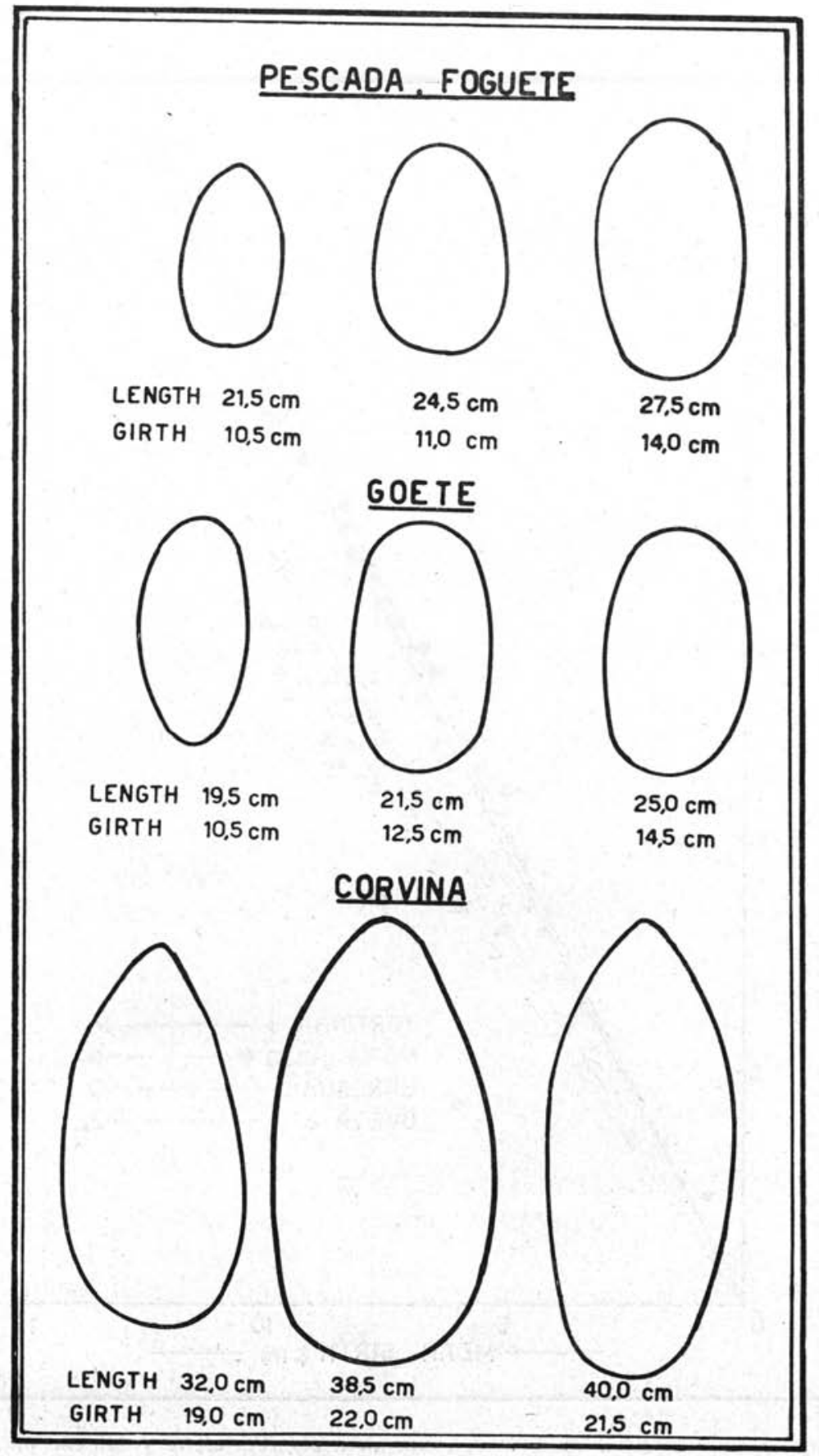

Fig. 2-Cross sections of Pescada-foguete, Corvina and Goete in the region of maximum girth. 


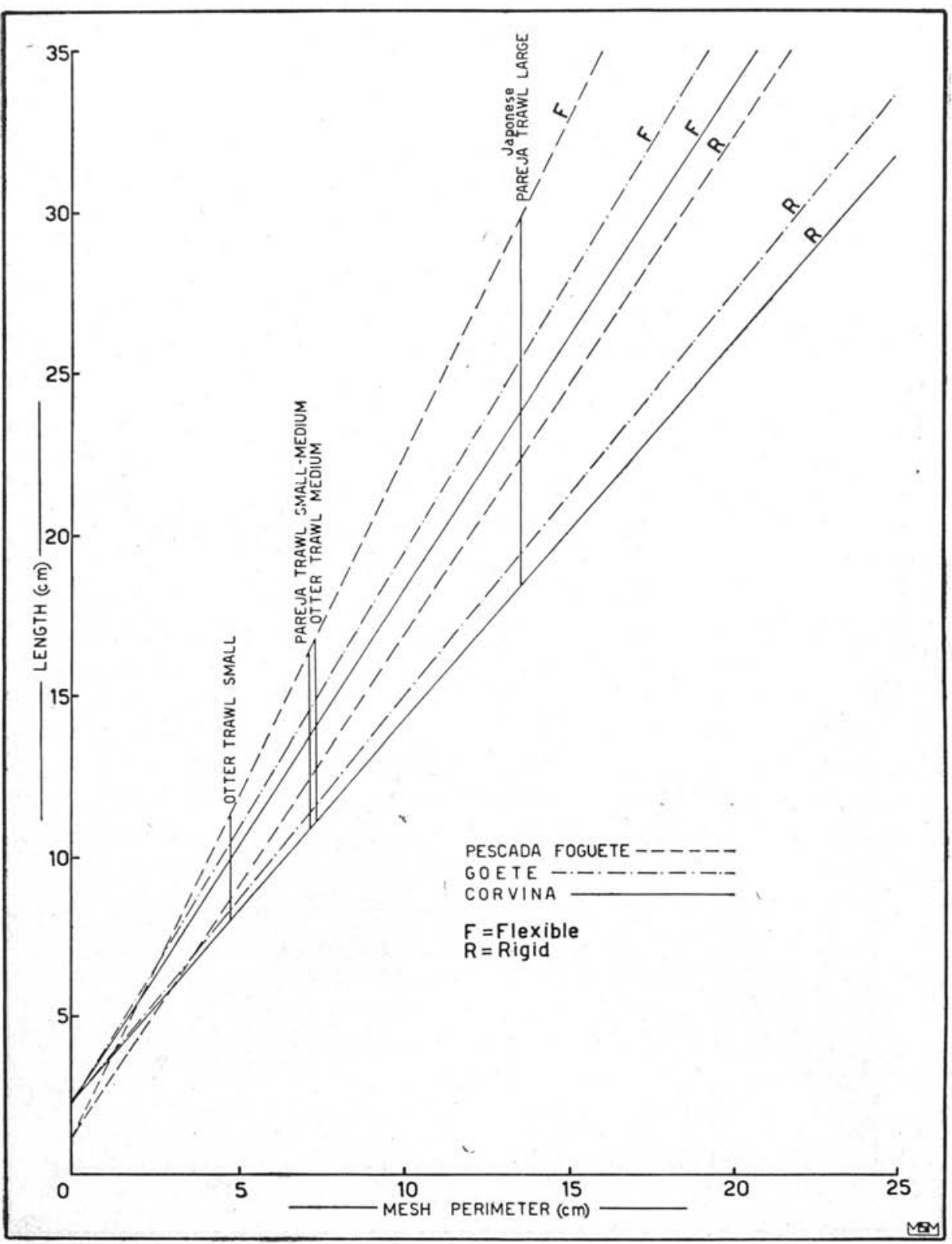

Fig. 3a - Regression of length against internal mesh size, assuming the mesh to be perfectly flexible, and rigid with ratio of axis in the proportion of $2: 3$. 


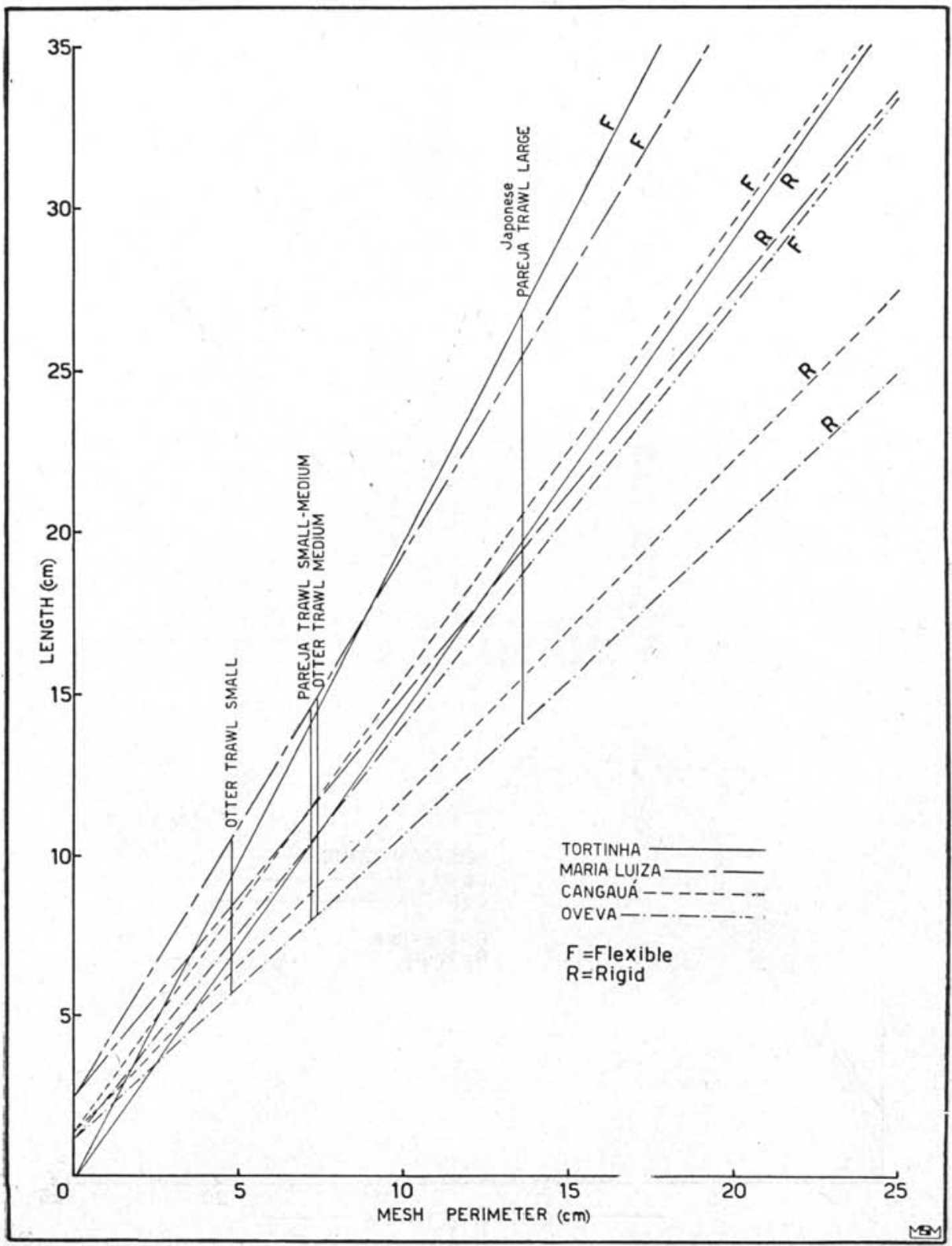

Fig. $3 b-$ Regression of length against internal mesh size, assuming to be perfectly flexible and rigid with the axis in the ratio of $2: 3$. 